\title{
Impact of Business Incubators on the Success of Small Textile Projects
}

\author{
Shaymaa Ahmed Mohamed Ahmed
}

Lecturer ( at Spinning, Weaving \& Knitting Department Faculty of Applied Arts, Beni Swief University , Egypt.)

\begin{tabular}{l|l|l|l|} 
Submit Date: 2020-05-09 22:07:20 & Revise Date:2021-05-21 18:12:49 & Accept Date: 2021-05-24 05:23:13
\end{tabular}

DOI: 10.21608/jdsaa.2021.29832.1030

KEYWORDS:

Business Incubators - Virtual Incubators - Organizational Resources - Small Projects - Micro Projects.

\begin{abstract}
:
No matter the definition of small-scale industries may differ from country to another, but there is an agreement that it is every project or industry based on activity of a limited number of staff, equipment and machines with a definite capital. Small-scale industries started to hold the attention of policy and economy planners around the world as per the importance of those industries in achieving the economic and social development because of its low-cost investments as well as its ability to scale-down percentage of unemployment suffered by many around the world.

Small-scale industries face many challenges including lack of funding sources, experiences, management skills of owners and technical expertise in using modern methods of productions and making processes for industries products. Advanced countries have established business incubators in order to overcome challenges and to help small-scale industries during their start-up and growth phases -as they are the most vulnerable stages- in order to provide all materials, technical advices, financial and technical services and enhancing the administrative skills for small-scale industries' owners.

Egypt's economy is in urgent need of an organization that supports small and micro-scale industries in order to achieve success for them which are considered as vital elements in motivating the domestic economy which suffers from failure and early collapse. Egypt shall follow the mechanism of business incubators in order to overcome the challenges facing those industries as it is the applied approach in advanced countries. Through this study Shedding the light on the reality of Egyptian business incubators, The researcher carried out a comprehensive inventory of all incubators in the Arab Republic of Egypt ,then classified the incubators in the following table identifying by: the name of each incubator / the owner of the incubator / the type of incubator / place of service delivery/ activity of the projects contained therein / the type of incubator in terms of the place of service providing and the duration of incubate projects, and what the incubator provides funding for the projects, then prepared questionnaire in order to determine the current status of the incubators, their services, the quality of the projects. they are embracing and their assistance to make the incubation success, The services provided by incubators for small
\end{abstract}


scale projects during and after the period of the incubation related of each incubation.( the results of the survey showed the ability to provide Success factors of projects incubation process (mean $=5.7$ from 10 ), the services required for small projects $($ mean $=7.07$ from 10$),($ mean $=$ to achieve its goals 6.18 from 10 )

At the end the research put conceptualization of the establishment of a new incubator is specialized in textile \& weaving field.

\section{Research problem:}

1. The rise in unemployment rates and the inability of the state sector to absorb these numbers so the urgent need to develop small and free industries absorbed these numbers.

2. The small industrial enterprises especially weaving one suffer from early failure problems Therefore, the need for research studies appeared the ability to shed light on industrial incubators which has the ability to solve this problem.

\section{Research objective:}

Standing on the reality of Egyptian business incubators, the current role they do and the challenges they face at the present time, and laying down the steps for those incubators to fulfill their role.\& the study also contributes to the decision makers of establishing workers incubators in realizing the most important factors that lead to the success of business incubators. Introduction: Small-scale industries are the real point for any economic and social progress in different countries of the world, there is no project has been generated big, as all projects are small and then they grow, therefore it was necessary for various countries of the world to direct a necessary care so that the innovative persons can create projects that have the ability to create job opportunities in order to advance the wheel of Economic growth for different countries (Ali, 2014) The experiences of many developed countries have proved the importance of Small-scale industries through establishing support networks that took several forms, most notably business incubators, and developing countries began to absorb the importance of business incubators in supporting Smallscale industries in achieving a remarkable qualitative breakthrough at the economic and social levels for those projects that have the ability to Create jobs at great rates from a small capital cost ( Chavis , Klapper \& Love 2011) and Egypt had to follow the same approach that these countries follow because it has industries in which it has significant comparative advantages that it has not been able to transfer to competitive advantages in the past decades, so these industries began to collapse, including textiles and leather, furniture and other industries, so The thought was to use business incubators and open small businesses ( Al-Bennan , 2003).

\section{1-Theoretical Study}

1-1 The concept of business incubators: The idea is inspired by the incubator in which children are placed immediately after birth in order to overcome the difficulties of the circumstances surrounding them to create the means of care (Al-Senussi \& Al-dwiby, 2003). National Business Incubator Association 2010: (NBIA) explained Business Incubators as a way to support start-up companies that provide them with assistance by providing them with a set of resources and services needed for these companies to be able to carry out their activities without obstacles, which helps to create jobs and enhance the national economy.

In light of the foregoing: The business incubators are the place equipped with all means of technical, administrative and financial support and managed by those who have expertise and specialized skills in all fields to build a network of internal and external relations with stakeholders to create a work environment for small investors and innovators depending on the philosophy that the small incubated projects are supportive for economic and social growth.

Hackett, S.M \& Dillts, D.M. (2004): Complete the previous definition, as an administrative working that has administrative skills and the ability to market the business incubator and the services it provides to incubated projects and follow-up the entrepreneurs during the incubation stages at regular intervals must be provided. (Hackett, \& Dillts, 2004).

Michael \& John (2002): see that the business incubator is a prepared and equipped place to provide consulting, services and financing, depending on the major investment companies (Michael \& John, 2002). Smilor, R.W (1987): had explained the business incubator as an innovative system that provides a set of support systems for entrepreneurs to accelerate and develop the performance of new companies and contribute to economic growth. (Smilor, 1987).

Risk Capital (Strenuous capital): It is one of the forms of financing for pilot projects in the early stage of construction of the project in which the investment is characterized by high risks. Investors of strenuous capital receive returns as a result of obtaining stakes 
in the project (Michael \& John, 2002).

Incubate: is the owner of a project that spends the incubation period in the incubator.

Alumni: is the owner of a project that ended the incubation period and graduated from the incubator.

Virtual business incubator: An incubator that does not have a place to provide its services through it but through the Internet and depends on technological progress (Are, \& Alf, 2016).

1-2-The historical development of the concept of business incubators: the idea dates back to the fifties after the Second World War and the increase in recession and unemployment when the Joseph Mancuso family transformed their company that stopped working for the first business incubator for manufacturing (Batavia) in New York, where its units are rented out to those wishing to establish a project while providing them with advices. The idea met a great success because the center was located in a business area closes to banks, shopping places, and

since 1959, thousands of small companies have been established in this center (Mekhemer , 2009). The historical development of business incubators had passed through three stages in the following table:

\section{Table (1) illustrates the historical development of} business incubators

\begin{tabular}{|c|c|c|c|}
\hline $\begin{array}{l}\text { Time } \\
\text { period }\end{array}$ & \multirow{2}{*}{$\begin{array}{c}\text { First } \\
\text { Generation } \\
1950 \mathrm{~s}- \\
1980 \mathrm{~s}\end{array}$} & \multirow{2}{*}{$\begin{array}{c}\text { Second } \\
\text { Generation } \\
1980 \text { s - } \\
1990 \text { s }\end{array}$} & \multirow{2}{*}{$\begin{array}{c}\text { Third } \\
\text { Generation } \\
\text { mid } 1990 \mathrm{~s}- \\
\text { present }\end{array}$} \\
\hline $\begin{array}{l}\text { Period } \\
\text { Features }\end{array}$ & & & \\
\hline $\begin{array}{c}\text { Name of } \\
\text { the } \\
\text { period }\end{array}$ & $\begin{array}{l}\text { Infrastructure- } \\
\text { economies of } \\
\text { scale }\end{array}$ & $\begin{array}{l}\text { Business } \\
\text { support: } \\
\text { accelerating } \\
\text { the learning } \\
\text { curve, } \\
\text { including } \\
\text { knowledge } \\
\text { based } \\
\text { services }\end{array}$ & $\begin{array}{l}\text { Networks: } \\
\text { facilitating } \\
\text { access to } \\
\text { external } \\
\text { resources, } \\
\text { knowledge } \\
\text { and } \\
\text { legitimacy }\end{array}$ \\
\hline Offering & $\begin{array}{l}\text { Office space } \\
\text { and shared } \\
\text { resources }\end{array}$ & $\begin{array}{l}\text { Coaching } \\
\text { and training } \\
\text { support } \\
\text { including } \\
\text { knowledge } \\
\text { based } \\
\text { services. }\end{array}$ & $\begin{array}{c}\text { (Internal) } \\
\text { Access to } \\
\text { technological } \\
\text {, professional } \\
\text { and financial } \\
\text { networks }\end{array}$ \\
\hline $\begin{array}{c}\text { Concept } \\
\text { or } \\
\text { Theoreti- } \\
\text { cal } \\
\text { Rationale }\end{array}$ & $\begin{array}{c}\text { Economies of } \\
\text { scale }\end{array}$ & $\begin{array}{c}\text { Accelerating } \\
\text { the learning } \\
\text { curve }\end{array}$ & $\begin{array}{l}\text { Access to } \\
\text { external } \\
\text { resources, } \\
\text { knowledge } \\
\text { and } \\
\text { legitimacy } \\
\text { (AliA, } \\
2000 \text { ). }\end{array}$ \\
\hline
\end{tabular}

\section{1-3-Business Incubator Stages:}

- Basic studies stage: It is the stage of searching for financing and gathering information about the place in order to establish the business incubator project and the micro-projects targeted for sponsorship and determining the expected financial costs.

- Feasibility study implementation stage: where the place and preparation required for operating the incubator are designed.

- Initial operation stage: Some initial projects are operated and the incubator is not operated with its full capacity.

Permanent operation stage: the stage in which the incubator begins its duties in receiving and sponsoring Small-scale industries during incubation and after the graduating of the project, the incubators and providing full support and consulting for the project, transferring technology and marketing for the incubator projects, i.e., working with the full capacity of the place (Are, \& Alf, 2016).

\section{1-4-Types of business incubators:}

Business incubators sponsored by state institutions (governmental): aim to achieve local development by promoting the activity of Small-scale industries by providing financial support from state institutions and they are non-profitable.

Business incubators owned by the private sector: aiming for profit by having returns for the organization that owns the incubator.

Business incubators in universities: are incubators that work to provide services and create a bridge for communication between industrial societies, scientific research and society as a whole for its ability to transfer scientific research to industrial / service products that are not for profit but can achieve self-sufficiency by providing training courses outside the incubator.

Mixed business incubators: These are incubators that have established a partnership between the private sector and private associations with the public sector and are jointly funded by those two sides (Abdel-Aal, 2005).

1-5-Basic services and facilities provided by business incubators:

- General business services: This includes the provision of public utility services, security, guards, warehouses, reception and secretarial services, meeting rooms.

- Administrative services: services on how to draw up business plans, publicity, advertising, product design and development, and human resource develop- 
ment.

-Professional services and network linkage: Communication services by creating a network of incubator external relations from major company owners, accountants, lawyers, marketers, venture capitalists and relationships with other incubators and government agencies to provide facilitation and facilitation for the incubator's business and projects (Nabil, 1995).

- Financial consulting: To educate project owners on how to obtain the appropriate capital for the project, provide financial advisory services, how to obtain bank loans, how to prepare budgets and contracts, and how to deal with taxes and customs.

- University business services: Provides specialized technical and administrative consultations through faculty members, providing office information and comprehensive training on entrepreneurship and increasing opportunities for leadership and management training. (Abdel- Aal , 2005).

\section{1-6-Life cycle of the incubated project:}

1- Pre-incubation stage. 2- Incubation stage that divided into: Stage of establishment and joining to the incubator. Project growth and development. 3- graduation from the incubator.

1-7-The Factors Influencing Performance Improvement of Business Incubators: The following figure illustrates the factors influencing performance improvement of business incubators.

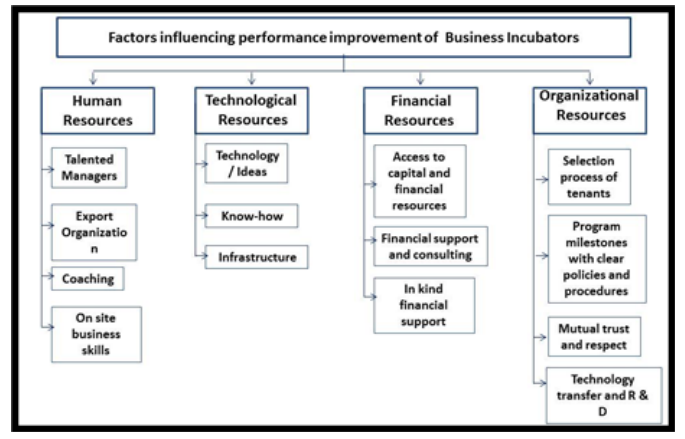

Figure (1) illustrates the factors influencing performance improvement of business incubators (Idris, 2011).

\section{1-8-The experience of leading countries for busi-} ness incubators:

American experience: Incubator industry pioneer, since the first day of the incubators' establishment, it managed to overcome the failure of large companies by converting buildings and workshops for business incubators for Small-scale industries to solve economic crises and provide job opportunities through incubated projects (Ledward \&Hirata, 2011).

Japanese experience: an experience with a distinctive cultural specificity due to the high awareness and culture of the Japanese citizen, his absolute love for the state, his dedication to work and his constant desire to develop his performance and excellence, and the scarcity of the natural resources surrounding him. For these industries, providing advice from experts specialized in the technical, administrative, and organizational fields, and providing courses and seminars for the owners of these industries (Camellia, 2012).

German experience: It is characterized by what are called innovation centers that are characterized by the expansion of their area and high technologies that are based on the development of industrial products and complement the small industrial projects incubated by major industries, and what distinguishes this experience is also the presence of joint structures (from a representative of the public authorities represented in the state and owners of major companies, universities and members From workers in incubators) to take decisions related to incubator policies and the type of projects that are incubated and through which joint programs are established for training, research and product development and optimal use of resources to ensure the continuity of the work Business incubators (Ledward, \& Hirata, 2011).

1-9-Small-scale industries: The concept of Small-scale industries differs from one country to another according to their different economic and social capabilities and conditions, and also varies according to the purpose of the project and its sources of financing and according to the statistical nature of the country. (De Strauss, 2019). 1-10-Small-scale industries in Egypt: The definition remained unspecified for the concept of small industries until the law 141 of 2004 was issued, the small establishment was: a company or establishment that engages in economic, production, or commercial activity with a paid-up capital of at least 50,000 pounds and not more than one million pounds, and the number of workers does not exceed 50 workers. And this definition was developed in accordance with Law 15 of 2017, that small industrial projects are all establishments that carry out an industrial activity only, the annual size of their business is not less than one million pounds and not more than 50 million pounds. About 50,000 pounds and does not exceed 5 million pounds (Report of the to engage in working life, distance from market Central Agency for Public Mobilization and Statistics, 2017).

1-11-Smallscale industries of spinning, weaving Fabric, hand -textile and handmade - carpets: Smallscale industries represent the dominant pattern of projects in Egypt, where Egypt has 2.4 million small scale 
industries, representing about 95 total Egyptian projects in general, and contain about 6.3 million of the total manpower, other than the agricultural sector, which are labor-intensive projects (Abu Raia 2005). They distribute income more evenly than large projects. artisanal textile industries are considered as one of small scale industries and also the mechanism that depend on a limited number of workers, and which vary in the ratings of 5 workers; Less than 100 workers, these industries are in the advanced position of community development; they are units (some mechanical and some manual) for the production of spinning, mechanical weaving, printing units, staining, handmadewoven fabric, handmade -carpets, and garment production units, jellaba, dusters , The natural handmade-silk fabric( Idris, 2011), (The Carpet and Rug Institute, 2019).

1-12 Characteristics of small scale industries in spinning, weaving(textile) and carpet:

- The lack of absolute capital invested, which made it a private property dominated by individuals, families or companies of persons .

- Its low infrastructure requirements and rapid deployment .

- it can cope with difficulties in times of economic crisis and recession because of its ability to adapt to evolution, innovation, and resilience according to variables, both in quantity and sort of production.

- It encourages young people unemployment and terrorism. (Abu Raia,2005).

- It is considered as one of the most important means of providing opportunities for young people and female heads of household in different governorates for their ability to contribute to the geographical distribution of their industry.

- It maintains heritage works that are of the utmost importance to preserve our original identity of oblivion and to help attract tourist and increase export opportunities (Report of the National Council for Education and Scientific and Technological Research , 2003), (Farrell , 2001).

- 2- Practical study:

- 1-The researcher carried out a comprehensive inventory of all incubators in the Arab Republic of Egypt, which was about ; 17 incubators of business, the State has 3 incubators,the private sector and civil associations have 10 incubators, Research bodies and universities, both governmental or private, have 4 incubators.

- 2-The researcher then classified the incubators in the following table identifying by: the name of each incubator / the owner of the incubator / the type of incubator / place of service delivery/ activity of the projects contained therein / the type of incubator in terms of the place of service providing and the duration of incubate projects, and what the incubator provides funding for the project.

- Table (2) illustrates the classification of Egyptian incubators.

\begin{tabular}{|c|c|c|c|c|c|c|c|c|}
\hline Name & 离 & $\stackrel{\Xi}{\stackrel{2}{2}}$ & . & : & 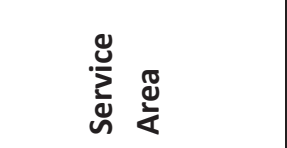 & 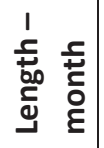 & 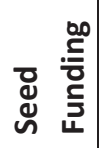 & $\frac{\vec{z}}{5}$ \\
\hline $\begin{array}{l}\text { Business Incubators for the } \\
\text { Development of Small and } \\
\text { medium enterprises }\end{array}$ & & 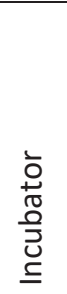 & 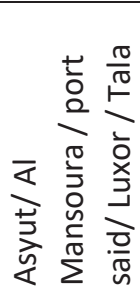 & & 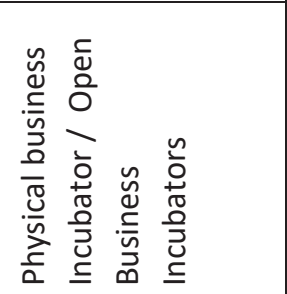 & & & \\
\hline Bedaya Incubator & & $\begin{array}{l}\overline{0} \\
\frac{0}{0} \\
\frac{0}{\omega}\end{array}$ & & $\overline{\bar{z}}$ & 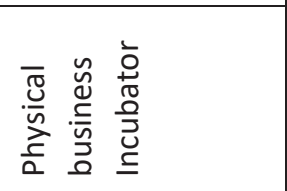 & $\ddot{m}$ & $\stackrel{\tilde{u}}{>}$ & \\
\hline $\begin{array}{l}\text { TIEC } \\
\text { Technology \& Innovationand } \\
\text { Entrepreneurshi }\end{array}$ & 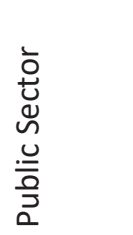 & 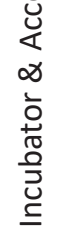 & 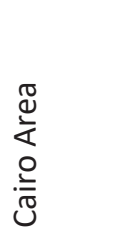 & 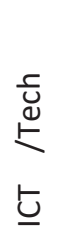 & 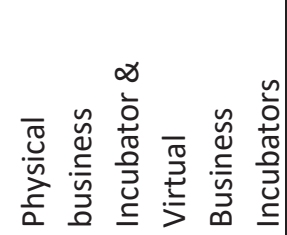 & ส & 20 & \\
\hline
\end{tabular}




\begin{tabular}{|c|c|c|c|c|c|c|c|c|}
\hline Innoventures & \multirow[b]{2}{*}{ 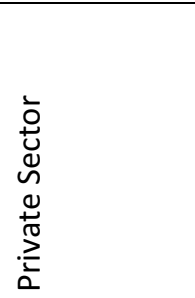 } & \multirow{5}{*}{ 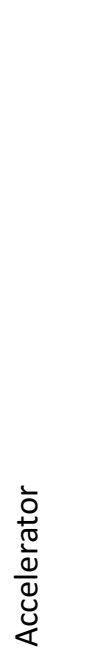 } & 号 & \multirow[b]{2}{*}{ 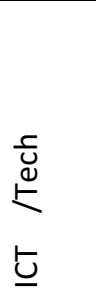 } & \multirow[b]{8}{*}{$\frac{\overrightarrow{3}}{\frac{3}{0}}$} & 6 & 2 & ' \\
\hline Ebni & & & 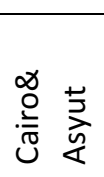 & & & $\stackrel{\varphi}{\dot{m}}$ & & ஸे \\
\hline JuiceLabs & \multirow{4}{*}{ 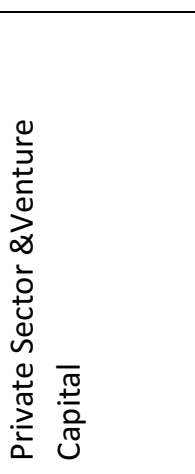 } & & & 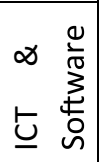 & & 6 & & 旤 \\
\hline Ideavelopers & & & & & & ' & & \\
\hline Flat6labs & & & & $\underline{\underline{E}} \underline{\frac{c}{\mathscr{Q}}}$ & & $\diamond$ & $\stackrel{\Perp}{\nu}$ & ○̆ ํํㄱ \\
\hline Sustaincubator & & \multirow{2}{*}{$\begin{array}{l}\frac{1}{0} \\
\frac{0}{0} \\
\frac{0}{3} \\
\underline{0}\end{array}$} & & & & $\underset{\ddot{m}}{\stackrel{\sim}{n}}$ & 은 & \\
\hline Injaz Egypt & \multirow{3}{*}{ 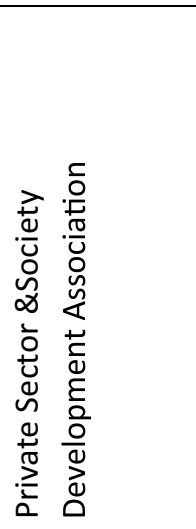 } & & & & & $\begin{array}{l}\varphi \\
\dot{m}\end{array}$ & $\stackrel{y}{\nu}$ & ' \\
\hline Greek Campus & & 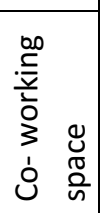 & & 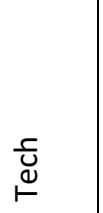 & & , & ○े & ઠें \\
\hline Nahdet el Mahrousa & & 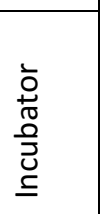 & & & 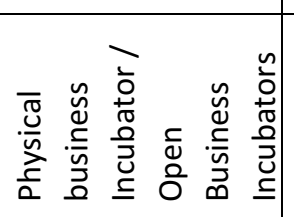 & 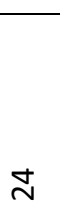 & 운 & , \\
\hline GESR Incubator & 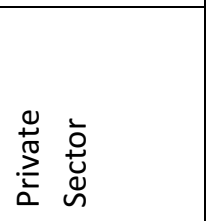 & 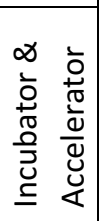 & 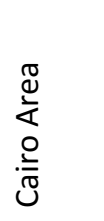 & 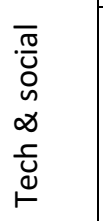 & \multirow{2}{*}{ 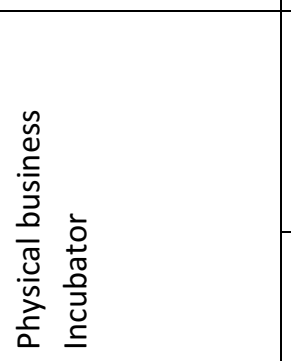 } & $\underset{\leftrightarrow}{\stackrel{7}{6}}$ & $\stackrel{\Perp}{\nu}$ & $\stackrel{\circ}{\stackrel{\ominus}{\ominus}}$ \\
\hline Hmaa & \multirow{2}{*}{ 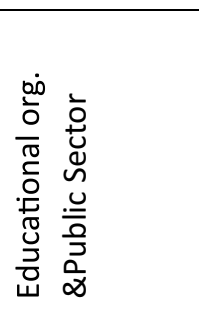 } & 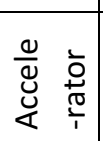 & 菨 & 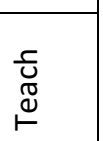 & & $m$ & , & \\
\hline El Teben & & & & $\bar{\varepsilon}$ & 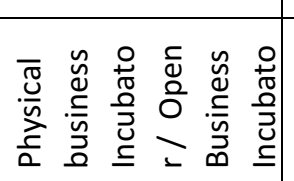 & $\stackrel{m}{m}$ & & \\
\hline AUC Venture Lab & 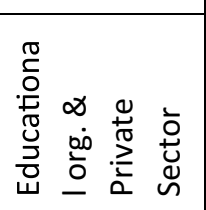 & & & $\begin{array}{l}\frac{c}{\mathrm{U}} \\
\stackrel{\mathrm{U}}{-}\end{array}$ & 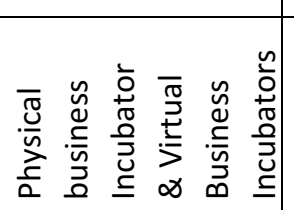 & $\stackrel{\infty}{\dot{n}}$ & $\stackrel{\check{y}}{>}$ & , \\
\hline $\begin{array}{l}\text { The Faculty of Economics and } \\
\text { Political Science Incubator }\end{array}$ & 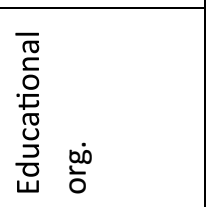 & 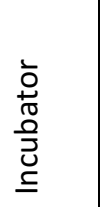 & 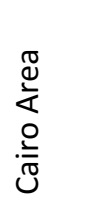 & 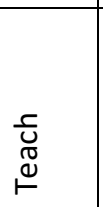 & 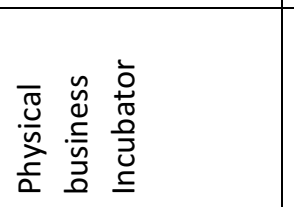 & ' & ' & ' \\
\hline
\end{tabular}


which headquartered in Assiut, as well he works of the two Eebni the two Eebni.as the Greek Campus because it expressed its way to rent space

3-The researcher has prepared the following questionnaire in order to determine the current status of the incubators, their services, the quality of the projects. they are embracing and their assistance to make the incubation success, The services provided by incubators for small scale projects during and after the period of the incubation related of each incubation. 4-The study sample was selected from 14 of the total 17 incubators in Egypt after excluding a business incubator of HMAA due to its distance and inability to travel based at Assiut University, computer and Information College. Also included are $t$ for small scal e projects and provide services for a fee)The study sample as shown in the following tables was divided by the number of graduates and incubators, the proportion of them with the sample, the owners of incubators, the type of projects, the number of personnel in the project, the legal form of the project, and whether a feasibility plan and study was prepared for the project before the start and the years of experience of these individuals in the area of entrepreneurship are a total of 215 who are the total respondents to the survey questions.

Table (3a) illustrates distribution of study sample according to relationship with the incubation.

\begin{tabular}{|l|l|l|}
\hline Study Sample & Number of people & \multicolumn{1}{c|}{ Percentage } \\
\hline Incubates & 120 & $\begin{array}{c}\frac{120 \times 100}{215} \\
=55.82 \%\end{array}$ \\
\hline Graduates & 95 & $\begin{array}{l}95 \times 100 \\
215 \\
=44.18 \%\end{array}$ \\
\hline Total & & $\mathbf{1 0 0 \%}$ \\
\hline
\end{tabular}

Table (3b) illustrates distribution of study sample according to incubation ownership.

\begin{tabular}{|l|l|l|}
\hline Sector Owner & Number of people & Percentage \\
\hline Public Sector & 82 & $38.14 \%$ \\
\hline Private Sector & 77 & $35.81 \%$ \\
\hline Educational org. & 56 & $26.05 \%$ \\
\hline Total & 215 & $100 \%$ \\
\hline
\end{tabular}

Table (3c) illustrates distribution of study sample according to the type of project associated to the incubation.

\begin{tabular}{|l|l|l|}
\hline Project Type & Number of people & Percentage \\
\hline Artificial & 28 & $13 \%$ \\
\hline Agricultural & 5 & $2.3 \%$ \\
\hline Service Project & 10 & $4.7 \%$ \\
\hline Technology & 172 & $80 \%$ \\
\hline Total & $\mathbf{2 1 5}$ & $\mathbf{1 0 0} \%$ \\
\hline
\end{tabular}

Table (3d) illustrates distribution of study sample according to number of employees.

\begin{tabular}{|l|l|l|}
\hline Num. of Worker & Number of people & Percentage \\
\hline From $1: 5$ & 150 & $70 \%$ \\
\hline From $6: 10$ & 43 & $20 \% 2$ \\
\hline From $11: 15$ & 15 & $7 \%$ \\
\hline$>15$ & 7 & $3 \%$ \\
\hline Total & $\mathbf{2 1 5}$ & $\mathbf{1 0 0} \%$ \\
\hline
\end{tabular}


Table (3e) illustrates distribution of study sample in terms of the legal form of the project.

\begin{tabular}{|l|l|l|}
\hline Legal Form of the Project & Number of people & Percentage \\
\hline Unregistered & 11 & $5 \%$ \\
\hline Registered & 204 & $95 \%$ \\
\hline Total & $\mathbf{2 1 5}$ & $\mathbf{1 0 0 \%}$ \\
\hline
\end{tabular}

Table (3f) illustrates distribution of study sample according to Prepare a plan \& feasibility study

\begin{tabular}{|l|l|l|}
\hline Prepare a plan \& feasibility study & Number of people & Percentage \\
\hline Yes & 209 & $97 \%$ \\
\hline No & 6 & $3 \%$ \\
\hline Total & $\mathbf{2 1 5}$ & $\mathbf{1 0 0 \%}$ \\
\hline
\end{tabular}

Table $(3 \mathrm{~g})$ illustrates distribution of study sample according to number of experience years.

\begin{tabular}{|l|l|l|}
\hline Years of Experience & Number of people & Percentage \\
\hline$<1$ Year & 86 & $40 \%$ \\
\hline From 1:3 Years & 50 & $23 \%$ \\
\hline From 3:5 Years & 58 & $27 \%$ \\
\hline$>$ 5 Years & 21 & $10 \%$ \\
\hline Total & $\mathbf{2 1 5}$ & $\mathbf{1 0 0 \%}$ \\
\hline
\end{tabular}

\section{Survey}

\section{General data:}

Name:

Age:

Gender:

Academic qualification:

Name of incubator which fostered you:

Kind of incubator: Governmental sector. Private sector Following educational institution Following a charity. Shared among more than one entity. Which kind do you prefer ......

Your years of experience in entrepreneurship:
Less than 1 year
1 to 3 years
3 to 5 years
more than 5 years

Your relation to the incubator:

Receiver of incubation Graduate An official in the incubator Expert

\section{Project data:}

Name of project: Address of project

Year of establishment: Date of beginning project incubation

Date of the graduation of project and people receiving incubation:

Kind of project: Industrial Agricultural service-oriented project technological Number of workers and employees: Period of project incubation:
Legal form of the project:
registered
unregistered
other

Did you prepare a written plan and a feasibility study for the project before establishment?

Success factors of projects incubation process (please put a degree from 1: 5): 
Table (4) illustrates Success factors of projects incubation process.

\begin{tabular}{|c|c|c|}
\hline & Statement & $\begin{array}{l}\text { Your } \\
\text { evaluation }\end{array}$ \\
\hline 1 & $\begin{array}{l}\text { Business incubator always search for novelty in information and } \\
\text { communication technology and provide information and consultations }\end{array}$ & \\
\hline 2 & It contributes in developing your thought as an entrepreneur. & \\
\hline 3 & $\begin{array}{l}\text { Business incubator provides you with the suitable training programs } \\
\text { which help you implementing your thoughts and developing your } \\
\text { technical and management skills. }\end{array}$ & \\
\hline 4 & The incubator can find an official financial sponsor for the project. & \\
\hline 5 & There is a clear plan for the mechanism of incubator work. & \\
\hline 6 & There is an efficient management for the incubator. & \\
\hline 7 & $\begin{array}{l}\text { The incubator administration continuously develop the quality of the } \\
\text { services provided for the person receiving incubation. }\end{array}$ & \\
\hline 8 & $\begin{array}{l}\text { The incubator contributes in increasing the number of people working } \\
\text { on the project and create new job opportunities. }\end{array}$ & \\
\hline 9 & $\begin{array}{l}\text { The incubator helps your project to overcome all problems and } \\
\text { obstacles facing the project to ensure continuity after the period of } \\
\text { incubation. }\end{array}$ & \\
\hline 10 & $\begin{array}{l}\text { Small-scale industries are considered one of the most important } \\
\text { methods of supporting Egyptian economy. }\end{array}$ & \\
\hline 11 & $\begin{array}{l}\text { The incubator contributed in establishing new local and global } \\
\text { participations with big companies and with your project. }\end{array}$ & \\
\hline 12 & $\begin{array}{l}\text { The incubator established a network of public relations which relate } \\
\text { among general and private sector and scientific research. }\end{array}$ & \\
\hline
\end{tabular}

Services provided by business incubation for Small-scale industries:

Table (5) illustrates Services provided by business incubation for Small-scale industries

\begin{tabular}{|c|c|c|}
\hline & Financial and technical services & $\begin{array}{l}\text { Your } \\
\text { evaluation }\end{array}$ \\
\hline 1 & $\begin{array}{l}\text { The incubator informs you with financing sources appropriate for your } \\
\text { project and coordinate between you and such financial institutions. }\end{array}$ & \\
\hline 2 & $\begin{array}{l}\text { The incubator contributes in purchasing machines, equipment and } \\
\text { tools necessary for your project. }\end{array}$ & \\
\hline 3 & $\begin{array}{l}\text { The incubator contributes in providing financial support necessary for } \\
\text { the expansions of your projects in its different stages of development. }\end{array}$ & \\
\hline 4 & $\begin{array}{l}\text { The incubator contributes in preparing feasibility studies and plans of } \\
\text { operations and drafting the budgets of your projects. }\end{array}$ & \\
\hline 5 & $\begin{array}{l}\text { The incubator contributes in providing the headquarter appropriate } \\
\text { for project. }\end{array}$ & \\
\hline 6 & $\begin{array}{l}\text { The incubator contributes in providing maintenance that your project } \\
\text { needs. }\end{array}$ & \\
\hline \multirow[t]{2}{*}{7} & $\begin{array}{l}\text { The incubator contributed in providing a reference information library } \\
\text { to benefit from during implementing your project. }\end{array}$ & \\
\hline & Administrative and information services & $\begin{array}{l}\text { Your } \\
\text { evaluation }\end{array}$ \\
\hline
\end{tabular}




\begin{tabular}{|c|c|c|}
\hline 1 & $\begin{array}{l}\text { The incubator contributes in preparing commercial and industrial } \\
\text { records, appropriate evaluation and supervision programs for your } \\
\text { projects. }\end{array}$ & \\
\hline 2 & $\begin{array}{l}\text { The incubator provides labor required by your project and also } \\
\text { provides accountants, drafts budget and prepare plans for your } \\
\text { project. }\end{array}$ & \\
\hline 3 & The incubator helps you in acquiring modern administrative methods. & \\
\hline 4 & $\begin{array}{l}\text { The incubator contributes in the issuance of publications and work of } \\
\text { documentations necessary for your project. }\end{array}$ & \\
\hline \multirow[t]{2}{*}{5} & $\begin{array}{l}\text { The incubator contributes in providing computer services and services } \\
\text { of reception, fax, telephone and website for your project. }\end{array}$ & \\
\hline & Marketing services & $\begin{array}{l}\text { Your } \\
\text { evaluation }\end{array}$ \\
\hline 1 & $\begin{array}{l}\text { The incubator contributes in designing strategies of launching the new } \\
\text { product in targeted markets of your projects. }\end{array}$ & \\
\hline 2 & Incubator contributes in providing electronic promotion for project. & \\
\hline 3 & $\begin{array}{l}\text { The incubator contributes in providing information and statistics } \\
\text { necessary for opening new markets and information about competitor } \\
\text { with your project. }\end{array}$ & \\
\hline
\end{tabular}

Do you want to demand any other services from the business incubator?

5-After the survey was conducted on the study sample, the results were compiled, all of which were given a score according to satisfaction, then the number and proportion of people were grouped for a preference that the incubation ownership. The average and proportion of factors that influence the success of the incubation process, the average and the satisfaction ratio. Financial and technological services, the results were as described in the following tables ( where the following statistic was used to analyze the results : statistical analysis using the statistical package SPSS V.22 / Percentages and frequencies to describe samples / Arithmetic mean / Cronbach Alpha Test to know the stability of survey paragraphs / $\mathrm{T}$ - Test to verify the significance of the Arithmetic mean for each paragraph of the survey / Pearson Correlation Coefficient to measure the degree of Correlation ) .

Table (6) illustrates Results of Survey.

\begin{tabular}{|l|l|l|l|l|l|}
\hline \hline \multirow{2}{*}{ Survey items \& results } & T-test & Std. Deviation & \multicolumn{2}{|l|}{ Mean } \\
\cline { 2 - 7 } & Sig & T & Statistic & $\begin{array}{l}\text { Std. } \\
\text { Error }\end{array}$ & Statistic \\
\hline $\begin{array}{l}\text { Success factors of projects incubation } \\
\text { process }\end{array}$ & 0.002 & 5.168 & - & 5.7 & \multicolumn{2}{|l|}{} \\
\hline $\begin{array}{l}\text { Services provided by business incubation } \\
\text { for Small-scale industries }\end{array}$ & 0.001 & 6.53 & 4.54 & 0.302 & 7.07 \\
\hline $\begin{array}{l}\text { The ability of business incubation to } \\
\text { achieve its goals }\end{array}$ & 0.000 & 4.614 & - & 6.18 & \\
\hline
\end{tabular}

From the previous table, it becomes clear that the sample of survey find the current Egyptian business incubations have the ability to provide Success factors of projects incubation process (mean $=5.7$ from 10 ) , the services required for small projects $($ mean $=7.07$ from 10$),($ mean $=$ to achieve its goals 6.18 from 10$)$ 


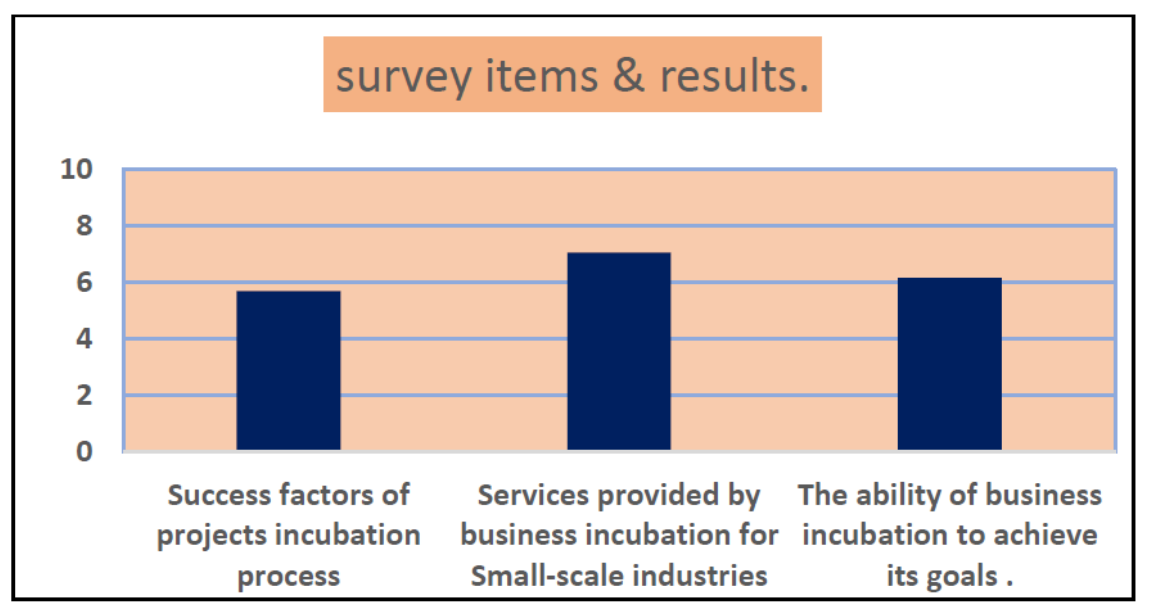

Figure (2) لillustrates the survev items \& results.

6-After making site visits to incubation and talking to several types of incubators, and after compiling the results of the survey, the researcher has been able to see the current status of Egyptian incubators, It can be summarized in the following points:

- The absence of the role of Supervisory Authority of the Egyptian business incubator, which was established since 1995 and was effective until 2007, there is no headquarters or website, it does not play the central role as planned at the beginning of the experiment, but it suspend its activity. It does not act as a coordinator among all sectors and the absence of its role in the process of evaluating the performance of incubators.

- In particular, all industrial projects can obtain bank loans only by providing a guarantor of the project. Incubators do not act as guarantors of these projects most of which are loanings without financing of delivering money, calculating interest, and not participating in the profit and loss as a implicit partner and the weakness of marketing services for industrial projects, which is the most dangerous service in this field (most incubators provide services in a typical way that does not seek the immediate needs of each project separately). There is no unified authority to finance Egyptian business incubators, and few venture capital incubators, reducing the chances of embracing ideas for innovative projects.

- There is no proliferation of Egyptian business incubators in all governorates, the majority of which are in the scope of Greater Cairo, the scarcity of incubators for universities and research bodies, and the scarcity of incubators for business in industrial conglom- erates making it more difficult for small industries to reach large companies, and the shortage of industrial projects $13 \%$ Projects in the textile field represent 3\% of the total projects involved This is a very low rate for this large sector , 2.3\% agricultural field and $4.7 \%$ service field, which is considered as the majority of projects involved in the field of communication ( Report of the National Council for Education and Scientific and Technological Research , 2003).

- The best properties of the business incubators are mixed incubators for their ability to provide marketing and financial support and to provide venture capital, private-owned business incubators come then incubators owned by government and the administrative level of the incubators is weak as the main reason for this, and incubators owned by the academic sectors at last level, there is no role for universities in establishing incubators.

- Most of the business incubators have a poor relationship with the industry community, given the lack of experience of workers and managersas a result of their lack of training in incubator management and their inability to understand needs of these industries, and this problem is clearly reflected in the incubators of the government sector.

- It does not have an agreed-upon process for managing and evaluating the performance of Egyptian business incubators, nor does it have a basis for evaluating the success or failure of the project that has been embraced.

- The term of the incubation is limited to the Egyptian incubators, the majority of which is not more than one year (the international incubators range from 3 
: 5years).

- It is not the stage after graduation from the incubator from work of the Egyptian incubators, which is the most important stage in supporting project, knowing the feasibility of incubation process, and the problem is clearly reflected in the incubators owned by the public and academic sectors and clearly reduced in incubators owned by private $\&$ mixed sector.

- The inability of small-scale industrial enterprises to choose the appropriate technology and the adoption of textile projects depends on primitive technologies, which reduce their production rates, some of which depend on advanced technologies and large investments which do not capture the capacity of the plant and the capabilities of the worker.

- The lack of spaces to accommodate industrial projects, if available, is high-cost.

- The State's failure to provide adequate incentives for domestic industrial products produced by small scale enterprises and their interest and support only for large enterprises and their products, resulting in its inability to compete with its low-price imported products, which weakens its competitiveness and sometimes threatens to close the project.

- The reduction in customs tariffs on textile and imported industrial products, the shortage of Egyptian raw materials, the high prices of imported raw materials, the difficulty of providing imported raw materials, especially for small scale entrepreneurs, the inability of the State to analyze international agreements to benefit from them and to avoid their effects on small and micro-scale domestic industries.

The absence of a social and Egyptian culture of the importance of small scale projects, especially the industrial ones, and the reluctance of many Egyptians to have their own projects and crafts the permanent social view of the preference and respect for the office work of productive craft

After considering the current situation of Egyptian incubators and of the industrial and textile projects that were embraced, the researcher's vision was to overcome these obstacles and to take advantage of the international experience in the field of business incubators as follows:

- It is important to establish a supervised authority to revive the role of the Egyptian business incubator group to supervise Egyptian business incubators with different types of property, act as a coordinator among all sectors, oversee the establishment of new business incubators, act as a link between incubators and industry, and finally to communicate with business incubators in all countries of the world to benefit from Their experiences, The performance of the Egyptian incubators follows and evaluates them in the light of economic, social and political changes and provides complete information and statistics on their small-scale projects, and the existence of its body coordinates with the body overseeing the development of the skills, assistance, efficiency and existence of its strategic development body To formulate general policies and plans for the establishment of business incubators and for the activation of continuous development mechanisms and small scale projects.

- The project of developing industries, small scale and inherited crafts, is considered the national project of Egypt in the coming period.

- A scientific and technological database that explains the needs of Egypt and the countries outside the products of small scale projects and prepares analytical studies for each individual field of the raw materials required and their availability / sources of supply / centers of China / relevant administrative bodies- and calculating the size of the local and international market And preparing future studies for the development of this organization.

- Establish a unified microfinance agency that will search for the appropriate investor for each project against the percentage of incubators' profits from the project's revenues and on banks and financial institutions to provide support to small scale projects Providing concessional loans to incubators, especially university incubators should be able to overcome the economic stagnation that large industrial firms encounter by qualifying them and expanding external markets and linked it to small-scale enterprises in its incubators, helping large firms in recession by ransforming their headquarters to business incubators for a material return from large firms.

- The existence of an economic authority to activate mechanisms for providing raw materials, whether domestic or import from abroad, to become small and large industrial projects in order to demand raw materials and machines with the technologies required to develop the industry with the lowest material return and to activate tax exemptions, Restrictions on the import of products competing with products of small industries (like Turkey and Brazil (18) at the start of their small enterprises, obtaining a credit from all sectors of their imports emulating the Egyptian heritage), establishing an international center for crafts 
and Egyptian heritage industries in all countries of the world and facilitating the participation of smallscale industry.

- The spread of Egyptian business incubators in all governorates, the increase in the number of incubators belonging to universities, research and scientific bodies, and the establishment of business incubators in industrial gatherings, (To facilitate the access of small-scale industries to large companies, there will be cooperation between what large industrial firms need from small parts that small enterprises can offer), diversity in the creation of business incubators in all disciplines, Giving priority to industrial, agricultural and craft projects and not limiting the role of incubators to communication and information technology projects.

- Establish an external relations network to become long-term relationships between incubators, hosts, and external partners such as local and international companies, chambers of commerce, investors and universities to transform the incubator as a medium to support emerging industrial projects to transform ideas for new products .

- The incubators of industrial works in Egypt should make the stage after graduation from the incubator within the stages of the incubation if not the most important of them at all in order too know the impact of what the nurse has received on the project, the incubators have a risk management program that is to reduce the risk ratio in the projects involved at all stages of the project And finding solutions to all the challenges that the project may face in all its different stages. (marketing problems and product and service development).

- Business incubators must adopt the latest systems of embracing small enterprises (planning, organizing, leading/monitoring, and monitoring), to be managed by a team with leading and creative thinking, It sets out the real needs of each small project on a one-toone basis for different requirements of each industry, different needs of each project and the duration of the incubation for each project, and has the capacity to develop intellectual capital and make optimal use of it, It has the potential to develop innovation in terms of its capacity to develop and modernize production processes faster and more cost-effectively.

- The Ministry of higher Education and Technical Education should be adopted to establish business incubators in cooperation with the industry community,Students adopt and learn the importance of self-employment and gain the industrial character of Egypt such as handmade tissue, pottery,wooden works, and raise awareness of the concept of business incubators and Its role is to support small industrial projects(through educational and training programs, seminars and lectures on the role of business incubators ).

- The need to develop technical education, a tie with crafts and small industries, and develop its graduation so that the competitor can develop and each graduate has the capacity to set up a small industrial project for the development of the local economy.

- The necessity of having a part of the small industrial projects that are included in the requirements of environmental tourism or finding what is known as the tourism of the traditional crafts and the authorities responsible for tourism support these projects and provide them with the plan of the presence of all its nationalities of tourists and their preference for the kinds of Egyptian heritage rich in its subcivilizations, African, Coptic. Islamism, the contemporary.

- Establish hypothetical business incubators to facilitate the creation of projects and companies to move toward optimal utilization of human resources and to create a working environment that is interlinked between the major strategic manufacturers and projects that have been developed and to be a link between university and the centers of technological excellence to enable private sector to participate in supporting the national economy.

- A network of Egyptian official business incubators should be established in order to communicate and coordinate all activities by providing concrete and non-concrete services to small-scale industrial projects .

The conceptualization of the establishment of a new incubator is specialized in the field of industrial and textile projects as follows:

1- The incubator of business as any project to be considered, whether in terms of generating thought, through an economic feasibility study and ending with a project registration, is like any institution that needs capital and its sponsors, In our case, large textile companies, which assist in their financing operations, specialized faculties, both government and private, and research and training centers can be used to provide them with experts and textile specialists, This will determine what services the incubation can provide to these entities in exchange for their financial support and the services they provide to industry and 
society as a whole. Projects that will be embraced and divided are phased in to start-up projects gradually depending on the capacity of the cubant.

2- The incubation belongs to the owner, and in this case it is preferable to be owned by the state or mixed property between the government and the private sector so that it can promote the textile industry and eliminate the challenges which faced either with technical and advisory support to major companies, or by providing the database on industry and availability of raw materials in cooperation with the sole supervisor of incubators It resolved the problem of high prices and energy of gazoles and the creation of a consensus between agriculture and industry by providing the needs of national industry, which in turn went to low-quality, low-price products .

3- The incubator must adopt the latest international methods of embracing small-form projects (fixed dates for accepting small projects and innovative ideas and the conditions are stated The project's stages or thought, and the services provided by the incubate are announced at each stage of the project and the individual needs of each project The small, textile, clothing, and tricolor projects that are dependant on machines such as spinning, weaving, clothing, and tricolor are different from manual projects such as carpet, handball, 1embroidery and traditional tricolor industries).

4- It is managed by team with a leading thought and extensive training in order to keep up-to-date with the latest knowledge of incubator .

5- The incubator of business as any project to be considered, whether in terms of generating thought, through an economic feasibility study and ending with a project registration, is like any institution that needs capital and its sponsors, In our case, large textile companies, which assist in their financing operations, specialized faculties, both government and private, and research and training centers can be used to provide them with experts and textile specialists, This will determine what services the incubation can provide to these entities in exchange for their financial support and the services they provide to industry and society as a whole. Projects that will be embraced and divided are phased in to start-up projects gradually depending on the capacity of the cubant.

6- The incubation belongs to the owner, and in this case it is preferable to be owned by the state or mixed property between the government and the private sector so that it can promote the textile industry and eliminate the challenges which faced either with technical and advisory support to major companies, or by providing the database on industry and availability of raw materials in cooperation with the sole supervisor of incubators It resolved the problem of high prices and energy of gazoles and the creation of a consensus between agriculture and industry by providing the needs of national industry, which in turn went to low-quality, low-price products .

7- The incubator must adopt the latest international methods of embracing small-form projects (fixed dates for accepting small projects and innovative ideas and the conditions are stated The project's stages or thought, and the services provided by the incubate are announced at each stage of the project and the individual needs of each project The small, textile, clothing, and tricolor projects that are dependant on machines such as spinning, weaving, clothing, and tricolor are different from manual projects such as carpet, handball, 1embroidery and traditional tricolor industries).

8 - It is managed by team with a leading thought and extensive training in order to keep up-to-date with the latest knowledge of incubator management and international experience in the field of weaving control To draw on their experience in the establishment and management of the incubator and in the development of its strategic plan, and how to focus permanently on monitoring and developing the projects developed to identify and address the weaknesses of the project and to improve the efficiency and performance of the project at different stages The beneficiaries of the incubation follow up after the incubation period so that the project can fully rely on itself.

9- There are continuing contests for embracing the creative entrepreneurs of textile industry and the owners of micro-projects, and the need for the design process of the textile product should be emphasized Presenter's environmental requirements and the applicant has an assessment of achieving creative activity from putting ideas/finding the appropriate idea/ determining the appropriate production policy/expected stages of development/economics of developing thought and product.

There should be a permanent display of leading and inspiring models of global business incubators such as the American, Japanese, German, French, and Chinese experiences, and the promising ones such as the Brazilian and Thai experiences to take advantage of them (Fernandes , \& Jr \& Sbragia \& Borini ,2017), 


\section{The role of business incubators in developing the weaving industry:}

1. Providing financial cover, which is the main obstacle to the development and advancement of our weaving industry by granting or facilitating borrowing or participation.

2. Business incubators can absorb the weaving employment in case of economic, social or political crises (closing or changing the activity of large companies), by providing small weaving project ideas, training, facilities to start.

3. Business incubators lead to the development of intellectual capital and how to optimize it \& ability to develop innovation and creativity though technology transfer, marketing innovation weaving production process faster and at a much lower cost.

4. Business incubators have the ability to create permanent contact between industry, scientific, research, financial, marketing institution which helps in solving many weaving industry

5. problems and helps in exploiting research issues in developing the marketable industry.

6 . The small weaving incubated projects are in themselves one of the pillars of the economic development of the society.

Small scale enterprises are the base on which the hierarchy of industry is based at every time and place, the larger, the base of small scale industries, the top of the textile industrial hierarchy can increase without an imbalance to qualify for the building of competitive capacity and hence, export capacity and the value added will be increased in the Egyptian textile industrial component ( UNCTAD , 2013) .

\section{Results:}

1. The study clarified and quantified the current status of the Egyptian incubators of all kinds.

2. The study clarified the shortage in industrial incubator projects where the percentage $13 \%$ of the total incubator projects and in the textile field represent 3\% of the total projects involved this is a very low rate for this large sector.

3 . The study contributed to the mechanism for establishing a specialized incubator in clothing and weaving industries which arise in industrial clusters in order to serve major industries by small-scale industries' products and determine its role in raising the efficiency of weaving industry. (where there is one incubation specialized in weaving field affiliated to the Academy of Scientific Research in Tanta which opened the door to apply for it in October 2016, and despite its opening 4 years ago, its role and ability to achieve its goals are still intangible due to lack of funding) .

\section{References:}

1/ Ali, J. A , 2014, A mechanisms-driven theory of business incubation, International Journal of Entrepreneurial Behavior \& Research, Vol 20, No 4.

2/ Chavis, L.W., Klapper,L.F. \& Love , I. , 2011 , The impact of business environment on young firm financing, The World Bank Economic Review, Vol $25(3)$.

$3 \backslash$ Al-Bennan , A , 2003, small scale industries and solving the problem of unemployment, Al-Ahram Economic Book, No. 189.

4/ Al-Senussi. R, Al-dwiby, A.S.B, 2003, Business and Small-scale industries incubator, House of National Books, Benghazi.

5/ Hackett, S.M \& Dillts, D.M. 2004, Key success factors for business incubation in South Africa, South Africa Journal of science, Vol 9.

6/ Michael \& John, 2002, Social Capital and Modern Incubator ,Journal of Small Business and Entrepreneurship, Vol 15 .

7/Smilor, R.W, 1987, Structure, policy, services and performance in business incubator industry, Entrepreneurship: Theory \& Practice, Vol 12.

8 / Are, B \& Alf, S. S, 2016, Venture creation and award-winning technology through co-produced incubation, Journal of Small business and Enterprise Development, Vol 23, No 1.

9/ Mekhemer, A.A, 2009, Small and Medium Industries Role in Addressing Arab Youth Unemployment Challenges Arab Administrative Development Organization.

10/ Ali A, N, 2000, the future of small scale industries, The Conference of small enterprises and Development prospects in Egypt.

11 / Abdel-Aal, M. S, 2005, Guidelines for Industrial Development in the New Economy, The First Annual Conference of the Omani Economic Association, Muscat.

12/ Nabil, H. M, 1995, A model for measuring the success of small enterprises in the Arab Republic of Egypt, An unpublished PHD thesis, Faculty of commerce, Cairo university. Egypt.

13/ Idris, T. A. R, 2011, Analysis of the causes of Small-scale industries failure; Do entrepreneurs and owner of such projects have administrative and mar- 
keting skills, Scientific Journal "Afak Gadida, Faculty of Commerce, Al- Menofia University.

14/ Ledward. B \& Hirata.D, 2011, An Overview of 21st Century Skills, Kamehameha Schools Research \& Evaluation, Honolulu.

15/ Camellia, M,2012, business incubation - Favorable Environment for Small and Medium Enterprises Development, Theoretical and Applied Economics, Vol XIX, No 5.

16/ De Strauss, S, 2019, The Complete Guide for Small-scale industries, Jarir Bookstore.

17/ Report of the Central Agency for Public Mobilization and Statistics, 2017 Annual Statistical Book, General Indicators.

$18 \backslash$ Abu Raia, S, 2005, the role of small scale and craft industries in achieving development, Second National Conference on supporting competitive advantages of traditional Industries and Heritage Crafts, Social Development Fund.

19 / The Carpet and Rug Institute,CRI, 2019,

Available at : http://www.carpet-rug.org/Carpet-for-Business/Specifying-the-Right-Carpet/Carpet-and-Rug-Construction.aspx .(Accessed :1 January 2019).

20/ Report of the National Council for Education and Scientific and Technological Research, 2003, Technological Incubators, Specialized National Councils, Presidency of the Council of Ministers, 30th session. 21/Farrell,L.C, 2001, The entrepreneurial Age :Awaking the Spirit of Enterprise in people Companies and Countries, Allworth press, New York .

22/ Fernandes, C .C \& Jr, M \& Sbragia, R \& Borini, F. M, 2017, Strategic assets in technology - based incubators in Brazil, European Journal of Innovation Management, Vol 20, No 1.

23 / UNCTAD, 2013, Promote entrepreneurship in order to build productive capacities, United Nation Conference on Trade and Commerce, Council of Trade and Development, Investment and Projects Committee, 5th Session, Geneva. 